\title{
Review \\ Carbon Dot Nanoparticles: Exploring the Potential Use for Gene Delivery in Ophthalmic Diseases
}

\author{
Manas R. Biswal ${ }^{1,2,3,4, *,+}$ and Sofia Bhatia ${ }^{1,+}$ \\ 1 Department of Pharmaceutical Sciences, Taneja College of Pharmacy, University of South Florida, \\ Tampa, FL 33612, USA; bhatias@usf.edu \\ 2 Department of Internal Medicine, Morsani College of Medicine, University of South Florida, \\ Tampa, FL 33612, USA \\ 3 Department of Ophthalmology, Morsani College of Medicine, University of South Florida, \\ Tampa, FL 33612, USA \\ 4 Department of Molecular Genetics and Microbiology, College of Medicine, University of Florida, \\ Gainesville, FL 32610, USA \\ * Correspondence: biswal@usf.edu; Tel.: +1-813-974-8333 \\ + These authors contributed equally to this work.
}

Citation: Biswal, M.R.; Bhatia, S. Carbon Dot Nanoparticles: Exploring the Potential Use for Gene Delivery in Ophthalmic Diseases. Nanomaterials 2021, 11, 935. https://doi.org/ 10.3390/nano11040935

Academic Editor: Run Zhang

Received: 3 March 2021

Accepted: 1 April 2021

Published: 6 April 2021

Publisher's Note: MDPI stays neutral with regard to jurisdictional claims in published maps and institutional affiliations.

Copyright: (c) 2021 by the authors. Licensee MDPI, Basel, Switzerland. This article is an open access article distributed under the terms and conditions of the Creative Commons Attribution (CC BY) license (https:// creativecommons.org/licenses/by/ $4.0 /)$.

\begin{abstract}
Ocular gene therapy offers significant potential for preventing retinal dystrophy in patients with inherited retinal dystrophies (IRD). Adeno-associated virus (AAV) based gene transfer is the most common and successful gene delivery approach to the eye. These days, many studies are using non-viral nanoparticles (NPs) as an alternative therapeutic option because of their unique properties and biocompatibility. Here, we discuss the potential of carbon dots (CDs), a new type of nanocarrier for gene delivery to the retinal cells. The unique physicochemical properties of CDs (such as optical, electronic, and catalytic) make them suitable for biosensing, imaging, drug, and gene delivery applications. Efficient gene delivery to the retinal cells using CDs depends on various factors, such as photoluminescence, quantum yield, biocompatibility, size, and shape. In this review, we focused on different approaches used to synthesize CDs, classify CDs, various pathways for the intake of gene-loaded carbon nanoparticles inside the cell, and multiple studies that worked on transferring nucleic acid in the eye using CDs.
\end{abstract}

Keywords: photoluminescence; biocompatibility; clathrin- and caveolae-mediated; ocular gene delivery

\section{Introduction}

Over the last decade, gene therapy has presented as a possible and promising treatment for various genetic disorders, such as Parkinson's disease and immunodeficiency diseases, and has attracted significant attention in the field of medical sciences. The straightforward principle behind gene therapy is to correct the disease origin by delivering missing or defective gene products [1]. However, therapeutic approaches vary depending on the type of gene and mutation. Luxturna, the first Food and Drug Administration (FDA)-approved ocular gene therapeutic product was developed to treat Leber congenital amaurosis (LCA) patients with bi-allelic mutations in the RPE65 gene. Most of the ongoing therapies in different clinical trial phases are based on adeno-associated virus (AAV) vectors [2]. Due to small size capacity, high production costs, high immunogenicity, inflammatory responses, and invasive administration to the retina, viral gene delivery raises concerns [3]. This brings up basic research on non-viral vectors, such as different kind of inorganic nanoparticles (gold nanoparticles [4], magnetic nanoparticles [5], carbon nanotubes [6], nanodiamonds [7], graphene [8]) for nucleic acid delivery [9]. Moreover, NPs overcome various safety concerns as compared to viral vectors, such as cost-effectiveness, ease to customize, design, and optimize for cellular uptake, large DNA capacity which is a very critical factor to deliver large ocular disease gene. 
The combination of nanotechnology and medicine led to the emergence of nanomedicine whereby a nanomaterial platform is used for gene or drug delivery with diagnostic probe $[10,11]$. The enhances permeability and retention (EPR) effect has been a crucial basis for the development of Nano medicines [12]. Due to the EPR effect, the therapeutic effect of drug-loaded nanoparticles with appropriate size increases significantly [13]. In a study, Ideta et al. [14] confirmed the delivery of a poly ion complex (PIC) micelle encapsulating fluorescein isothiocyanate-labeled poly-L-lysine (FITC-P(Lys)) targeted to the choroidal neovascularization (CNV) lesions in rats. The results showed that PIC micelles had longcirculating features and were retained in highly permeable CNV lesions for $168 \mathrm{~h}$ after intravenous administration. These micelles were probably accumulating in CNV lesions through the EPR effect. These days, nanomedicine is a rapidly growing research area that aims to apply nanoparticles like metallic nanoparticles, semi-conductive quantum dots, carbon materials like graphene oxide or nanotubes for therapeutics, imaging, sensing, and stimuli-responsive carriers. Out of these, carbon dots have been identified as potential material for various nanomedicine applications $[15,16]$. Carbon-based nanoparticles are made only of carbonaceous nanomaterials. CDs were first discovered and observed by $\mathrm{Xu}$ et al. [17] during the separation of single-walled carbon nanotubes from carbon soot using the arc discharge method. C-dots are spherical shape nanocarriers with a diameter of $<10 \mathrm{~nm}$ [18]. They possess a carbon core with different functional groups (e.g., $-\mathrm{OH}$, $-\mathrm{COOH},-\mathrm{NH}_{2}$ ) on their surface which provides high biological activity, good water solubility ability to form conjugates with other organic and inorganic substances [19]). Due to the properties like extremely small size, ease of synthesis and modification, low cytotoxicity, the higher degree of oxidation, and good water retention [20], CQDs have been used in a wide number of the application; Fluorescent labeling and cell imaging [21], targeted drug delivery for cancer treatment [22], detecting heavy metal ions [23], bacterial labeling and detecting live/dead bacterial differentiation using charge-selective interaction [24].

The CDs synthesis procedures can be divided into two groups, namely top-down and bottom-up methods [25] (Figure 1). Various top-down synthesis methods such as laser ablation, arc-discharge, hydrothermal and electrochemical oxidation involve the breaking of bulk carbon precursors into nanosized particles [26]. The bottom-up method involves dehydration, polymerization, and carbonization of small carbon molecules which result in the formation of graphene quantum dots, and amorphous carbon nanodots via hydrothermal synthesis, microwave pyrolysis and solution chemistry [27]. Table 1 shows different fabrication methods used for CDs synthesis and their advantages and disadvantages.

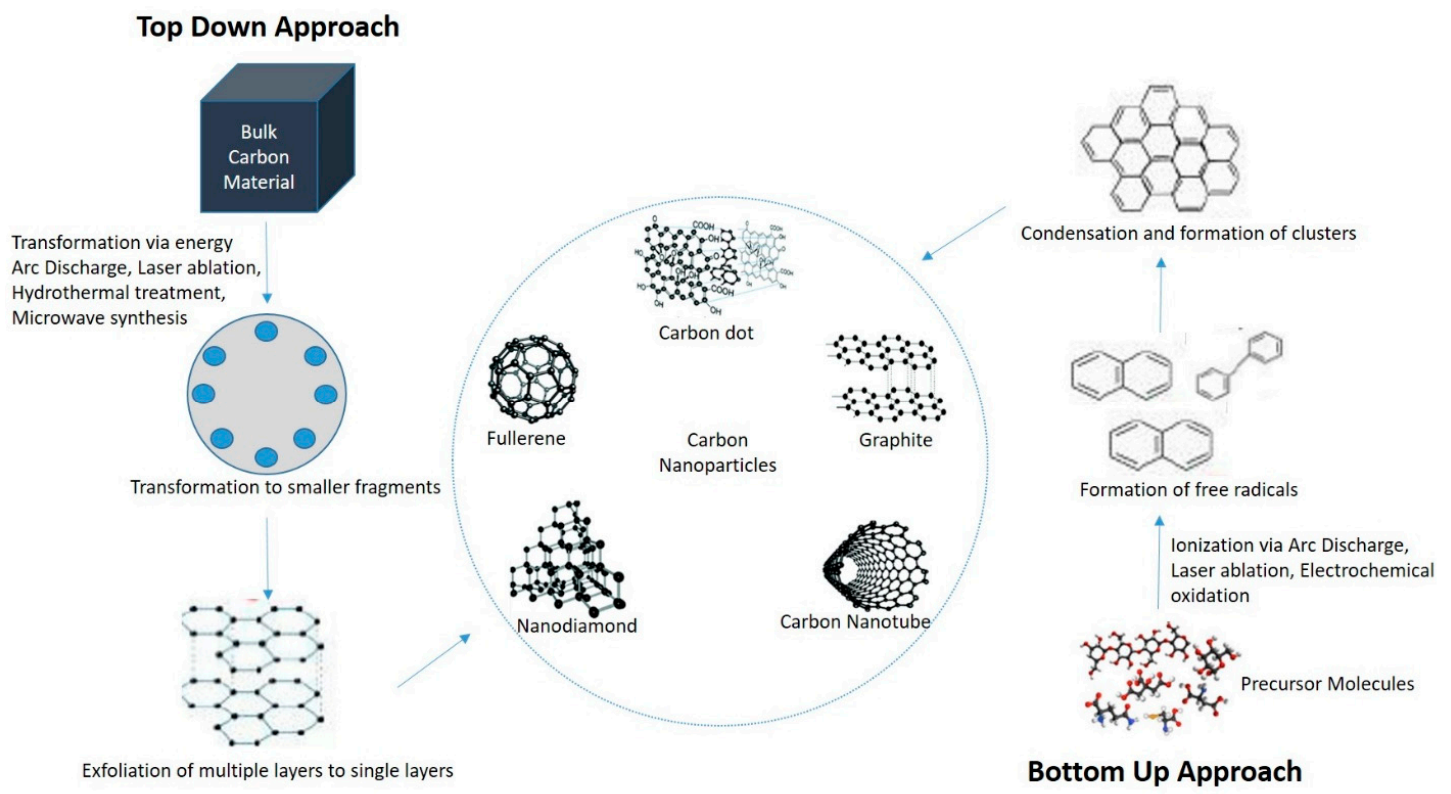

Figure 1. Various approaches and methods used to form carbon-based nanoparticles. 
Table 1. Advantages and disadvantages of different methods of C-dots synthesis.

\begin{tabular}{|c|c|c|c|c|c|c|c|c|}
\hline Strategies & $\begin{array}{l}\text { Fabrication } \\
\text { Method }\end{array}$ & $\begin{array}{l}\text { Carbon } \\
\text { Source }\end{array}$ & $\begin{array}{l}\text { Size } \\
(\mathrm{nm})\end{array}$ & $\begin{array}{l}\text { Yield } \\
(\%)\end{array}$ & $\begin{array}{l}\text { Luminescence } \\
\text { Wavelength } \\
\text { (nm) }\end{array}$ & Advantages & Disadvantages & Ref. \\
\hline \multirow{3}{*}{ Bottom-up } & $\begin{array}{c}\text { Thermal } \\
\text { decomposition }\end{array}$ & sucrose & 1.84 & 21.6 & 365 & $\begin{array}{l}\text { Less time consuming, } \\
\text { easy to operate, low } \\
\text { cost, large scale } \\
\text { production }\end{array}$ & $\begin{array}{l}\text { Broad size } \\
\text { distribution }\end{array}$ & [28] \\
\hline & $\begin{array}{l}\text { Hydrothermal } \\
\text { treatment }\end{array}$ & citric acid & $2.69,3.10$ & 71,78 & $420-520$ & $\begin{array}{l}\text { Cheap, eco-friendly, } \\
\text { lack of toxicity, low cost }\end{array}$ & Low yield & [29] \\
\hline & $\begin{array}{l}\text { Microwave } \\
\text { synthesis }\end{array}$ & glucose & $2.75,3.65$ & $6.3,3.1$ & 330 & $\begin{array}{l}\text { Fast, low cost, eco } \\
\text { friendly }\end{array}$ & Poor size control & [30] \\
\hline \multirow{4}{*}{ Top-down } & $\begin{array}{l}\text { Electrochemical/ } \\
\text { chemical } \\
\text { oxidation }\end{array}$ & acetonitrile & 2.8 & 6.4 & 365 & $\begin{array}{c}\text { High yield, high purity, } \\
\text { low cost, control } \\
\text { over size }\end{array}$ & $\begin{array}{l}\text { Few small } \\
\text { molecule } \\
\text { precursors }\end{array}$ & {$[31]$} \\
\hline & Arc discharge & Arc soot & 18.0 & - & 365 & $\begin{array}{l}\text { Fabricate carbon NPs } \\
\text { in a variety of gases }\end{array}$ & $\begin{array}{l}\text { Require more } \\
\text { purification }\end{array}$ & [17] \\
\hline & Laser ablation & & & & & $\begin{array}{l}\text { Easy control over size } \\
\text { and photolumicense } \\
\text { property }\end{array}$ & $\begin{array}{l}\text { High cost and } \\
\text { sophisticated } \\
\text { process }\end{array}$ & {$[32]$} \\
\hline & $\begin{array}{l}\text { Ultrasonic } \\
\text { treatment }\end{array}$ & Waste food & 4.6 & 2.85 & $>400$ & $\begin{array}{c}\text { Convenient to break } \\
\text { large carbon materials, } \\
\text { well dispersed, low } \\
\text { crystallinity }\end{array}$ & High energy cost & [33] \\
\hline
\end{tabular}

There are different types of CDs such as graphene quantum dots (GQDs), carbon quantum dots (CQDs), carbon nanodots (CNDs), carbonized polymer dots (CPDs) depending upon the structure of carbon core, surface groups, and properties. GQDs consist of single or few layers of graphene sheets. GQDs have known to have better crystalline structure relative to $\mathrm{CDs}$ as the presence of $\mathrm{sp}^{2}$ carbon units in CDs have lower crystallinity as compared to GQDs [34]. CQDs constitute multilayered graphite structures connected with surface groups. CNDs are highly carbonized nanoparticles without obvious crystallinity. CPDs possess a polymer/carbon hybrid structure including several functional group chains on the surface and a carbon core [35].

\section{Properties of CDs}

CDs have attracted researcher because of their unique optical and physicochemical properties [36] which are discussed in this section.

\subsection{Absorption}

CDs showed strong absorbance in the $280-360 \mathrm{~nm}$ UV region with tail extending into visible region where absorption band are assigned to $n-\pi^{*}$ transition of $\mathrm{C}=\mathrm{O} / \mathrm{C}=\mathrm{N}$ bond or $\pi-\pi^{*}$ transition of $\mathrm{C}=\mathrm{C}$ bond $[37,38]$. The absorption band and emission properties of CDs can be regulated by types and content of surface modifications or surface functional groups, $\pi$-conjugated domains or variation of oxygen/nitrogen content in carbon core.

\subsection{Photoluminescence}

Photoluminescence (PL) is one of the most significant properties of CDs which make it an important material for biomedical applications. The PL nature of CDs depends on the size, morphology, concentration, internal structure, and composition of the particle. These features are regulated by the initial precursors and fabrication methods used to form CDs. Various methods such as hydrothermal carbonization and microwave synthesis can be used to elevate the PL of CDs by surface alteration. Various studies have reported that surface passivation could increase the PL activity of CDs. Some of the commonly used surface 
passivating agents are polyethylene glycol (PEG) and polyethyleneimine (PEI). Heteroatomdoped CDs have also been used to adjust the intrinsic features. Sahiner et al. [39], reported an easy and fast method to prepare $\mathrm{N}$ - and S-doped amino acid derived CDs in a single step using microwave irradiation in 2 min which increases the photoluminescence efficiencies.

\subsection{Quantum Yield (QY)}

QY of CDs is also an important parameter that depends on the raw material and fabrication method. It has been found that CDs fabricated from graphite, citric acid, and candle soot reported QY up to 10\%. Various studies have reported various approaches such as surface passivation or modification and element doping with nitrogen and sulfur [40] to increase the QY of CDs. Xu et al. [41] prepared sulfur-doped CDs with 67\% QY using the hydrothermal method. A study done by Zhuo et al. [42] reported $80 \%$ of QY while fabricating CDs using citric acid and glutathione as starting material. Hu et al. [43] prepared polyethyleneimine-based carbon dots (PCD) by the oxidation of polyethyleneimine with a QY of $54.3 \%$.

\subsection{Biocompatibility}

It is very complicated to determine the cytotoxicity of carbon nanoparticles. Various factors such as the presence of metal catalysts/graphite, surface coating, UV radiation exposure, dispersion properties, aggregation due to high Van der Waals forces affect the behavior of these particles [44]. Many studies investigated the cytotoxicity of CDs in vitro [11,45,46] as well as in vivo. In 1999, Huczko et al. [47] studied the toxic effects of fullerene matter on Draize rabbit and found no effects on the eye within 24, 48, and $72 \mathrm{~h}$, respectively. Later, Aoshima et al. [48] performed a toxicity study to find the safety of fullerenes used in the cosmetic industry on rabbit eyes. They found that fullerenes could cause redness in the conjunctiva and defects in corneal epithelia, but the symptoms disappeared in two days. However, it is difficult to know its effect on humans as most of the research was done on rat and rabbit eyes which are more sensitive to particles. Some of the latest studies reported non-toxicity in vitro experiments in CDs [32,49]. Zhang et al. [50] incubated CT26.WT and CAL-26 cells with $0.1-1 \mathrm{mg} / \mathrm{mL}$ CDs solution and evaluated the cytotoxicity of CDs on cells using MTT assay. The viability of cells after $24 \mathrm{~h}$ was found to be $>84 \%$ for CT26.WT cells and $>60 \%$ for CAL-27 cells at the concentration of $1 \mathrm{mg} / \mathrm{mL}$. In another study, Li et al. [51] evaluated cytotoxicity on fabricated C-dot-based nanohybrids with multihydroxy hyperbranched polyglycerol (HPG) at the concentrations of $0.1-10 \mathrm{mg} / \mathrm{mL}$. The study reported $\geq 90 \%$ cell viability at the concentration of $0.1-2.0 \mathrm{mg} / \mathrm{mL}$ and it decreases at higher concentrations. However, it is critical to investigate the safety and toxicity profiles of nanomedicine formulations in order to stimulate clinical translations of nanomedicine [52]. The generation of reactive oxygen species (ROS) by nanoparticles may cause toxicity. ROS may cause potential adverse effects such as cellular components damage. Tabish et al. [53] reported association of ROS with graphene cellular toxicity. Graphene-induced toxicity depends on its physiochemical interactions with other organs where it might be accumulated. Graphene-induced ROS may cause oxidative stress, loss of cellular functions, mitochondrial damage, lipid peroxidation, nucleic acid modifications, and inflammation, which lead to cell death and toxicity. To date, the mechanism and roles of ROS produced by graphene have not been fully explored. A study done by Tabish et al. [54], demonstrated a facile approach to manufacture GQD with high single oxygen yield and good biocompatibility by assessing the toxicity of GQDs in vivo as well as in vitro.

It is difficult to synthesize uniform size CDs. The size distribution is important as it decides the toxicity and fluorescence nature of CDs and it may obstruct their biological applications [55]. Different synthesis methods may result in different size, yield, fluorescence color, which can obstruct CDs commercialization [55]. There are multiple studies on the cytotoxicity of CDs in different concentrations in various cell lines. However, the role of the synthesis approach on the toxicity of fabricated CDs has not been fully explored 
yet [56]. A study done by Esfandiari et al. [56] studied the effect of carbonization degree in the synthesis of four different CDs on cytotoxicity, photo-induced toxicity, and cellular uptake under different experimental conditions. The authors synthesized CDs via citric acid thermal decomposition at different temperatures and time durations. The size, QY, the toxicity of synthesized CDs was characterized. The study demonstrated that the small changes in the synthesis conditions may have significant effects on the properties of CDs.

\section{How the CDs Deliver DNA/RNA to the Cells}

Carbon Nanoparticles can enter the cell by several processes such as phagocytosis [57], endocytosis, and micropinocytosis [58] (Figure 2). Endocytosis pathways can be classified into clathrin- and caveolae-mediated endocytosis, phagocytosis, macropinocytosis, and pinocytosis. The phagocytosis pathway is actin-dependent and limited to macrophages, dendritic cells, and neutrophils. They engulf foreign materials of large size ( $>0.5 \mathrm{um})$ [59]. Macropinocytosis is an actin-regulated process in which cells internalize fluids and particles together and form large size vesicles $(0.2-5 \mathrm{um})$ [59]. Actin assembly plays an important role in the uptake process because of the micrometer length scale of phagocytosis and macropinocytosis [60]. Pinocytosis involves the absorption of extracellular fluids, small molecules and, forms small vesicles of $100 \mathrm{~nm}$ size [59]. Receptor-mediated endocytosis (RME) is known to be a potential method for NPs uptake and it includes clathrin- and caveolae-mediated endocytosis. These pathways are important for the cellular internalization of NPs. In clathrin-mediated endocytosis, receptor-ligand binding initiates the formation of coated pits on the cytosolic side of the plasma membrane which further forms a closed polygonal cage [61]. In caveolin-mediated endocytosis, the assembly of hairpinlike caveolin coats was formed on the cytosolic side of the plasma membrane [62]. Both clathrin- and caveolin-mediated pathways were reported to have highly complex biochemical cascades [63]. Various features, such as shape, size, and physicochemical properties, of NPs regulate the rate and quantity of cellular uptake of NPs. Carbon dots incubated with different mammalian cell lines showed penetration of a small amount of carbon into the cell membrane and also showed favorable biocompatibility. Four cellular uptake inhibitors (glucose, filipin III, 5-(N,N-dimethyl)-amiloride (DMA) and chlorpromazine hydrochloride (CPZ)) were used to study the internalization mechanism of CDs/pDNA nanomaterials. The results showed strong fluorescence emission by DMA and no fluorescence emission by filipin III, glucose, and CPZ. It has been observed that CDs could internalize both plasmid DNA and siRNA via clathrin- as well as caveolae-mediated endocytosis to achieve effective gene expression as compared to macropinocytosis [15]. 


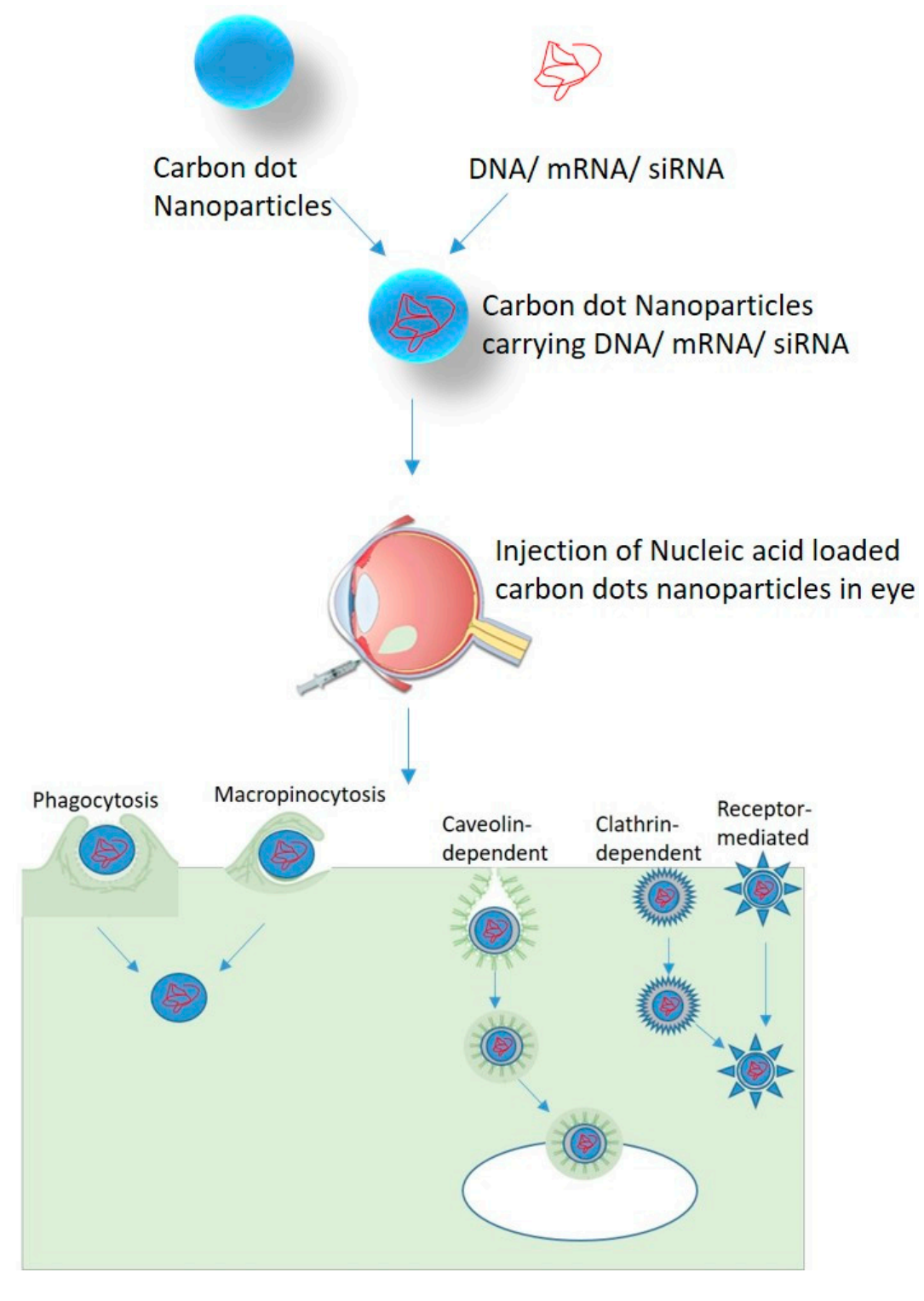

Figure 2. Nucleic acid delivery in retinal cells using carbon dots nanoparticles.

\section{CDs Efficiency in Gene Delivery}

In recent years, CDs have been successfully used for in vivo as well as in vitro bioimaging, and gene therapy. Folic acid (FA), hyaluronic acid (HA), RGD-peptide have been used as fluorescent probes in conjugation with $\mathrm{CDs}$ for disease diagnosis and therapy. Properties such as biocompatibility, less cost fabrication technique, lower cytotoxicity, water-solubility, effective binding with organic and inorganic molecules, different intake routes make CDs better for gene delivery as compared to other non-viral vectors. PEI has been commonly used cationic polymers in gene delivery. Liu and coworkers, [11] constructed highly efficient dual-functional nanoparticles which are based on PEI-passivated carbon dots (C-dots) by microwave assisted pyrolysis of glycerol in the presence of branched PE125k in one-step and demonstrated the use of CDs for in vitro gene delivery. In this hybrid C-dot, PEI played two important roles: one is surface passivation to endow the C-dots with strong photoluminescence, and second, DNA condensation for gene transfection. The capability of DNA condensation and cytotoxicity of CD-PEI depends on the pyrolysis time. Authors found that the CD-PEI which are obtained at appropriate pyrolysis time showed lower toxicity, higher gene expression of plasmid DNA in COS-7 cells and HepG2 cells. The fluorescent emission at various wavelength showed internalization of CD-PEIs into the cells which make CD-PEI as a potential application in gene delivery and bioimaging. 
Wang et al. [32], synthesized a novel photonic carbon dots (Cdots) based nanocarrier using low molecular weight amphiphilic PEI (Alkyl-PEI2k) for surface passivation. The results showed that Alkyl-PEI2k-Cdot nanocarrier is water-dispersible and possesses good stability, fluorescence, monodispersity with a narrow size distribution, low toxicity in cells, and high gene delivery efficiency.

Wang et al. [64], experimented to construct carbon dots where hyaluronic acid (HA) was used as a carbon source and polyethyleneimine (PEI) as a passivating agent using the synthetic method with no additives and validated the use of CDs for in vivo gene delivery. FT-IR and NMR results showed that some residues of HA and PEI remain in the HA-CDs structure. It has been observed that these materials had lower cytotoxicity than PEI and good serum tolerance. The authors found higher transfection efficiency (up to 50 times) in the presence of $10 \%$ serum. HA-CDs showed good intracellular imaging ability and fluorescence emission was observed under various wavelengths.

He et al. [65], prepared two cationic polymer-derived C-dots (Taea-CD and Cyclen$\mathrm{CD})$ using the hydrothermal method which has the potential to condense DNA into nanoparticles with a positive charge and provide protection to DNA from degradation. The results showed 2000 times higher transfection efficiency and also showed high serum tolerance and cell viability as compared to commercially available PEI. Due to the optical property of C-dots, better efficiency in the transfection process was observed by cell imaging and real-time detection using confocal laser scanning microscopy (CLSM) assay. Another study was done by Chen et al. [9], prepared CDs from low molecular weight PEI and modified them with various hydrophobic chains and different degrees of substitution. Analytical approaches like ${ }^{1} \mathrm{H}$ NMR spectroscopy, FT-IR spectroscopy, TEM, and XPS were used to confirm modification and substitution. Authors demonstrated the capability of CDs in bioimaging, and gene delivery and also found that the prepared CDs, Ole1.5-CD showed 200 times higher transfection than PEI $25 \mathrm{kDa}$ in the presence of serum in A459 cells. Table 2 shows previously reported studies for the delivery of gene using CDs.

Table 2. Studies reported use of CDs in gene delivery.

\begin{tabular}{|c|c|c|c|c|c|c|c|}
\hline CDs & Precursors & $\begin{array}{l}\text { Synthesis } \\
\text { Method }\end{array}$ & Size (nm) & QY (\%) & Ccell Lines & Findings & Ref. \\
\hline CD-PEI & glycerol & $\begin{array}{c}\text { Microwave } \\
\text { pyrolysis }\end{array}$ & $7-12$ & - & $\begin{array}{l}\text { COS-7; } \\
\text { HepG2 }\end{array}$ & $\begin{array}{l}\text { Constructed high efficient } \\
\text { nano gene vector with } \\
\text { strong photoluminence and } \\
\text { efficient transfection }\end{array}$ & [11] \\
\hline PCD & PEI & $\begin{array}{l}\text { Hydrothermal } \\
\text { reaction }\end{array}$ & $3-4$ & 54.3 & $\begin{array}{c}\text { MCF-7; } \\
293 \mathrm{~T}\end{array}$ & $\begin{array}{l}\text { Evaluated the use of PCD as } \\
\text { fluorescence probe for cell } \\
\text { imaging }\end{array}$ & [43] \\
\hline $\begin{array}{l}\text { CD-PDMA- } \\
\text { PMPD }\end{array}$ & citric acid & Microwave & 50 & 41.5 & COS-7 & $\begin{array}{l}\text { Displayed higher } \\
\text { transfection efficiencies and } \\
\text { provide a promising } \\
\text { platform for serum-resistant } \\
\text { gene delivery and imaging }\end{array}$ & [66] \\
\hline $\begin{array}{c}\text { siRNA- } \\
\text { Cdots@PEI }\end{array}$ & $\begin{array}{l}\text { CA, } \\
\text { tryptophan, } \\
\text { Nitrogen }\end{array}$ & $\begin{array}{c}\text { Microwave } \\
\text { prolysis }\end{array}$ & $4.7 \pm 0.8$ & 24.2 & MGC-803 & $\begin{array}{l}\text { Demonstrated the intake of } \\
\text { siRNA into gastric cancer } \\
\text { cells MGC- } 803 \text { causes gene } \\
\text { silencing }\end{array}$ & [32] \\
\hline CD/siRNA & $\begin{array}{c}\text { Citric acid, } \\
\text { branched PEI }\end{array}$ & $\begin{array}{c}\text { Microwave } \\
\text { prolysis }\end{array}$ & $12-13.2$ & $31.5-48.1$ & A549 & $\begin{array}{l}\text { Reported the potential of } \\
\text { CDs/siRNA delivery in } \\
\text { A549 cells for the treatment } \\
\text { of lung disease }\end{array}$ & [67] \\
\hline $\begin{array}{l}\text { fc-rPEI- } \\
\text { Cdots }\end{array}$ & $\begin{array}{c}\text { Glycerol and } \\
\text { PEI }\end{array}$ & $\begin{array}{c}\text { Microwave } \\
\text { pyrolysis }\end{array}$ & 143.1 & - & H460; 3Т3 & $\begin{array}{l}\text { Showed potential in lung } \\
\text { cancer targeting and } \\
\text { treatment }\end{array}$ & [68] \\
\hline
\end{tabular}


Table 2. Cont.

\begin{tabular}{|c|c|c|c|c|c|c|c|}
\hline CDs & Precursors & $\begin{array}{l}\text { Synthesis } \\
\text { Method }\end{array}$ & Size $(\mathrm{nm})$ & QY (\%) & Ccell Lines & Findings & Ref. \\
\hline $\begin{array}{c}\text { Positive } \\
\text { charge CDs }\end{array}$ & PEI and FA & $\begin{array}{l}\text { Hydrothermal } \\
\text { reaction }\end{array}$ & - & 42 & 293T; HeLa & $\begin{array}{c}\text { Reported a low cost } \\
\text { synthesis method that } \\
\text { exhibit photoluminescent } \\
\text { property for cancer } \\
\text { diagnosis and gene therapy }\end{array}$ & [69] \\
\hline HP-CDs & branched PEI & Hydrothermal & 2.25 & 12.4 & HeLa & $\begin{array}{l}\text { Evaluated great potential of } \\
\text { HP-CDs in tumor targeting, } \\
\text { intracellular imaging and } \\
\text { gene delivery }\end{array}$ & [70] \\
\hline CDs/pDNA & $\begin{array}{l}\text { Porphyra } \\
\text { polysaccharide- } \\
\text { EDA }\end{array}$ & hydrothermal & $<10$ & 56.3 & EMSCs & $\begin{array}{l}\text { Demonstrated more efficient } \\
\text { neuronal fifferentiation of } \\
\text { EMSCs with CDs/pDNA }\end{array}$ & [71] \\
\hline FCDs & $\begin{array}{l}\text { Tetrafluorotere } \\
\text { phthalic acid } \\
\text { and branched } \\
\text { PEI }\end{array}$ & $\begin{array}{l}\text { Solvothermal } \\
\text { process }\end{array}$ & $136 \pm 5$ & - & HEKT292 & $\begin{array}{c}\text { FCDs showed higher } \\
\text { transfection even in high } \\
\text { serum concentration and } \\
\text { low DNA dose }\end{array}$ & [72] \\
\hline CDs/pSOX9 & $\begin{array}{l}\text { Arginine, } \\
\text { glucose }\end{array}$ & $\begin{array}{c}\text { Microwave } \\
\text { prolysis }\end{array}$ & $10-30$ & 12.7 & MEFs & $\begin{array}{l}\text { Successfully delivered } \\
\text { pSOX9 into embryonic } \\
\text { fibroblast cells of mouse and } \\
\text { in vito results showed high } \\
\text { gene transfection efficiency }\end{array}$ & [1] \\
\hline
\end{tabular}

\section{Applications of CDs in Ocular Treatments}

Because of the unique properties of CDs, many studies have reported in vivo and in vitro gene delivery for different diseases using CDs. In recent times, some of the studies have reported the application of CDs in ocular gene delivery. A study done by Jian et al. [73] has synthesized carbon quantum dots (CQDs) from biogenic polyamines (PAs) and can be used as a promising antibacterial agent for the treatment of keratitis, a disease caused by microbial infections. High yield CQDs were synthesized using a one-step method by direct pyrolysis of spermidine (Spd) powder through a simple dry heating treatment. Authors demonstrated that CQDs obtained from Spd $\left(C D_{\text {Spds }}\right)$ have effective antibacterial activities against multidrug-resistant bacteria (methicillin-resistant $\mathrm{S}$. aureus) and nonmultidrug-resistant bacteria (E. coli, S. aureus, P. aeruginosa, and S. enterica serovar enteridis). Higher minimal inhibitory concentration (MIC) indicates good antibacterial capabilities. Evaluation obtained from in vitro cytotoxicity, hemolysis, hemagglutination, genotoxicity, and oxidative stress and in vivo morphological and physiological corneal changes indicates better biocompatibility of $\mathrm{CQD}_{\mathrm{Spds}}$. Hahn et al. [74] performed an experiment to treat retinitis pigmentosa (RP) using photosensitized-bonded carbon nanomaterial was covalently bonded to hyaluronic acid under lightless condition. The hyaluronic acid-carbon nanomaterial-photosensitizer complex prevents the formation of active oxygen in RPE cells for long period of time. The study manufactured CQD-Ce6 complex and HA-CQD-Ce6 complex and analyzed their effect on the prevention of active oxygen. It was confirmed that HA-CQD-Ce6 complex showed 80\% oxygen suppression ability while CQD-Ce6 showed $60 \%$ in the cells.

Using an MTT assay, it was confirmed that HA-CQD-Ce6 complex does not show cytotoxicity until the concentration of Ce6 reaches $100 \mathrm{ng} / \mathrm{mL}$. The RPE cells treated with HA-CQD-Ce6 and CQD-Ce6 was further treated with sodium iodate to check he cell viability. The results showed that the viability of cells in both complex treated RPE cells was lower as compared to sodium iodate treated cells. Authors also confirmed that RPE cells has hyaluronic acid receptor and they exhibit high cell uptake. The complex showed excellent therapeutic efficiency and very easily infiltrate in the cells. 
Hasanzedah et al. [75] developed CD-PEI as a traceable multicolor photoluminescent gene delivery nanocarrier by pyrolysis of a mixture of citric acid and branched PEI using a microwave approach. This is the first study that reported the transfer of pCRISPR to the cells by CD-PEI with high quantum yield. PEI not only play role in condensing DNA on the surface of CDs but also help in passivation. In vitro study using HEK 293 cell line showed low cytotoxicity and acceptable transfection efficiency. Nanodiamond (ND), another carbon-based nanomaterial used to carry biomolecules such as DNA, protein, and small drug molecules. Yang et al. [76] tested the possibility of using Nanodiamonds (NDs) based CRISPR-Cas 9 delivery system as a tool for creating in vitro and in vivo disease models of X-linked retinoschisis (XLRS). Authors designed NDs-based CRISPR-Cas9 delivery vector by functionalizing carboxyl (-COOH) group to the NDs surface and covalently conjugated with fluorescent 6 His-tagged mCherry reporter protein. mCherry protein is further conjugated with two linear DNA constructs; one Cas9 endonuclease with GFP reporter protein and another sgRNA containing HDR template insert which is designed to insert mutation (c.625C > T) in RS1, a gene associated with X-linked retinoschisis (XLRS) phenotype. These NPs were internalized by human iPSCs and mouse retinas via the endosome pathway. Authors demonstrated that mCherry protein remains stables in the retina for up to 2 weeks and the addition of BSA increases the efficiency of NDs.

Shoval et al. [77] performed a study to deliver an anti-VEGF aptamer across the corneal structure into the eye using a C-dots-aptamer hybrid system which inhibits the angiogenesis induced by VEGF in the posterior eye chamber. The hydrophobic properties of C-dots and hydrophilic properties of aptamer-functionalized surface domains increase the permeation of carriers through a highly complex corneal structure, consisting of hydrophilic stroma and hydrophobic epithelium. The fluorescence of anti-VEGF aptamer-functionalized C-dots helps in monitoring the intraocular concentration of drugs in the eye.

\section{Conclusions}

Many studies have made progress in utilizing various properties of CDs in optical, energy, and biomedical applications. A lot of research development is going on in CDs on their synthesis, structures, properties, and application development. In all carbon-based materials, research on CDs is still in a more emerging stage. So, there is a potential interest in producing good-quality CDs with desirable shape, size, crystallinity, number of functional groups, and types. In this review, we have briefly summarized types, synthesis methods, properties, different internalization pathways, and recent advances in the use of CDs in retinal gene therapy. Unique physicochemical properties such as photoluminescence and in vitro and in vivo studies showing the non-toxicity of $C D$ s have also been discussed. The stable photoluminescence and low cytotoxicity of CDs make them a potential candidate for bio-sensors, bio-imaging, drug delivery, and gene/plasmid/RNA delivery. Surface passivation or modifications of CDs with chemical groups are beneficial for functional hybrids, fluorescent nanocomposites, and high refractive index materials [78]. The synthesis process and biological applications of CDs are believed to be safe and biologically benign. Due to this, CDs could become a promising candidate to replace organic and inorganic quantum dots in the future.

Author Contributions: Conceptualization, M.R.B.; writing-original draft preparation, S.B. and M.R.B.; writing-review editing, S.B. and M.R.B.; supervision, M.R.B.; funding acquisition, M.R.B. All authors have read and agreed to the published version of the manuscript.

Funding: This research was funded by NIH/NEI award EY027013-02, USF Taneja College of Pharmacy startup grant to Manas R. Biswal.

Conflicts of Interest: The authors declare no conflict of interest. 


\section{References}

1. Cao, X.; Wang, J.; Deng, W.; Chen, J.; Wang, Y.; Zhou, J.; Du, P.; Xu, W.; Wang, Q.; Wang, Q.; et al. Photoluminescent Cationic Carbon Dots as efficient Non-Viral Delivery of Plasmid SOX9 and Chondrogenesis of Fibroblasts. Sci. Rep. 2018, 8, 1-11. [CrossRef]

2. Naso, M.F.; Tomkowicz, B.; Perry, W.L.; Strohl, W.R. Adeno-Associated Virus (AAV) as a Vector for Gene Therapy. BioDrugs 2017, 31, 317-334. [CrossRef]

3. Ray-Rico, A.; Cucchiarini, M. Supramolecular cyclodextrin-based hydrogels for controlled gene delivery. Polymers 2019, 11, 514. [CrossRef] [PubMed]

4. Tandon, A.; Sharma, A.; Rodier, J.T.; Klibanov, A.M.; Rieger, F.G.; Mohan, R.R. BMP7 Gene Transfer via Gold Nanoparticles into Stroma Inhibits Corneal Fibrosis In Vivo. PLoS ONE 2013, 8, e66434. [CrossRef]

5. Gandra, N.; Wang, N.-D.; Zhu, Y.; Mao, C. Virus-mimetic cytoplasm-cleavable magnetic/silica nanoclusters for enhanced gene delivery to mesenchymal stem cells. Angew. Chem. Int. Ed. Engl. 2013, 52, 11278-11281. [CrossRef] [PubMed]

6. Kates, K.; Kostarelos, K. Carbon nanotubes as vectors for gene therapy: Past achievements, present challenges and future goals. Adv. Drug Deliv. Rev. 2013, 65, 2023-2033.

7. Yang, H.; Liu, Y.; Guo, Z.; Lei, B.; Zhuang, J.; Zhang, X.; Liu, Z.; Hu, C. Hydrophobic carbon dots with blue disspersed emission and red aggregation-induced emission. Nat. Commun. 2019, 10, 1789. [CrossRef]

8. Imani, R.; Mohabatpour, F.; Mostafavi, F. Graphene-based Nano-Carrier modifications for gene delivery applications. Carbon 2018, 140, 569-591. [CrossRef]

9. Chen, P.; Zhang, J.; He, X.; Liu, Y.H.; Yu, X.Q. Hydrophobically modified carbon dots as a multifunctional platform for serumresistant gene delivery an dcell imaging. Biomater. Sci. 2020, 8, 3730-3740. [CrossRef]

10. Moghimi, S.M.; Symonds, P.; Murray, J.C.; Hunter, A.C.; Debska, G.; Szewczyk, A. A two-stage poly(ethylenimine)-mediated cytotoxicity: Implications for gene transfer/therapy. Mol. Ther. 2005, 11, 990-995. [CrossRef]

11. Liu, C.; Zhang, P.; Zhai, X.; Tian, F.; Li, W.; Yang, J.; Liu, Y.; Wang, H.; Wang, W.; Liu, W. Nano-carrier for gene delivery and bioimaging based on carbon dots with PEI-passivation enhanced fluorescence. Biomaterials 2012, 33, 3604-3613. [CrossRef] [PubMed]

12. Stylianopoulos, T.; Wong, C.; Bawendi, M.G.; Jain, R.K.; Fukumura, D. Multistage nanoparticles for improved delivery into tumor tissue. Methods Enzym. 2012, 508, 109-130. [CrossRef]

13. Acharya, S.; Sahoo, A.K. PLGA nanoparticles containing various anticancer agents and tumor delivery by EPR effect. Adv. Drug. Rev. 2011, 63, 170-183. [CrossRef] [PubMed]

14. Ideta, R.; Tasaka, F.; Jang, W.-D.; Nishiyama, N.; Zhang, G.-D.; Harada, A.; Yanagi, Y.; Tamaki, Y.; Aida, T.; Kataoka, K. Nanotechnology-Based Photodynamic Therapy for Neovascular Disease Using a Supramolecular Nanocarrier Loaded with a Dendritic Photosensitizer. Nano Lett. 2005, 5, 2426-2431. [CrossRef] [PubMed]

15. Mohammadinejad, R.; Dadashzadeh, A.; Moghassemi, S.; Ashrafizadeh, M.; Dehshahri, A.; Pardakhty, A.; Sassan, H.; Sohrevardi, S.-M.; Mandegary, A. Shedding light on gene therapy: Carbon dots for the minimally invasive image-guided delivery of plasmids and noncoding RNAs-A review. J. Adv. Res. 2019, 18, 81-93. [CrossRef] [PubMed]

16. Zuo, G.; Xie, A.; Li, J.; Su, T.; Pan, X.; Dong, W. Large Emission Red-Shift of Carbon Dots by Fluorine Doping and Their Applications for Red Cell Imaging and Sensitive Intracellular Ag+ Detection. J. Phys. Chem. C 2017, 121, 26558-26565. [CrossRef]

17. Xu, X.; Ray, R.; Gu, Y.; Ploehn, H.J.; Gearheart, L.; Raker, K.; Scrivens, W.A. Electrophoretic analysis and purification of flu-orescent single-walled carbon nanotube fragments. J. Am. Chem. Soc. 2004, 126, 12736-12737. [CrossRef] [PubMed]

18. Mishra, V.; Patil, A.; Thankur, S.; Prashant, K. Carbon dots: Emerging theranostic nanoarchitectures. Drug Discov. Today 2018, 23, 1219-1232. [CrossRef]

19. Hu, S.-L.; Niu, K.-Y.; Sun, J.; Yang, J.; Zhao, N.-Q.; Du, X.-W. One-step synthesis of fluorescent carbon nanoparticles by laser irradiation. J. Mater. Chem. 2009, 19, 484-488. [CrossRef]

20. Lim, S.Y.; Shen, W.; Gao, Z. Carbon quantum dots and their applications. Chem. Soc. Rev. 2015, 44, 362-381. [CrossRef]

21. Luo, P.G.; Yang, F.; Yang, S.T.; Sonkar, S.K.; Yang, L.; Broglie, J.J.; Liu, Y.; Sun, Y.P. Carbon-based quantum dots for fluores-cence imaging of cells and tissues. RSC Adv. 2014, 4, 10791-10807. [CrossRef]

22. Zheng, M.; Liu, S.; Li, J.; Qu, D.; Zhao, H.; Guan, X.; Hu, X.; Xie, Z.; Jing, X.; Sun, Z. Integrating oxaliplatin with highly lu-minescent carbon dots: An unprecedented theranostic agent for personalized medicine. Adv. Mater. 2014, 26, 3554-3560. [CrossRef]

23. Gao, X.; Du, C.; Zhuang, Z.; Chen, W. Carbon quantum dot-based nanoprobes for metal ion detection. J. Mater. Chem. C 2016, 4, 6927-6945. [CrossRef]

24. Hua, X.W.; Bao, Y.W.; Wang, H.Y.; Chen, Z.; Wu, F.G. Bacteria-derived fluorescent carbon dots for microbial live/dead differentiation. Nanoscale 2017, 9, 2150-2161. [CrossRef]

25. Garner, I.; Vichare, R.; Paulson, R.; Appavu, R.; Panguluri, S.K.; Tzekov, R.; Sahiner, N.; Ayyala, R.; Biswal, M.R. Carbon dots fabrication: Ocular imaging and theraputic potential. Front Bioeng. Biotechnol. 2020, 8, 573407. [CrossRef] [PubMed]

26. Chan, K.K.; Yap, S.H.K.; Yong, K.-T. Biogreen Synthesis of Carbon Dots for Biotechnology and Nanomedicine Applications. Nano Micro Lett. 2018, 10, 1-46. [CrossRef] [PubMed]

27. Wang, C.; Xu, Z.; Cheng, H.; Lin, H.; Humphrey, M.G.; Zhang, C. A hydrothermal route to water-stable luminescent carbon dots as nanosensors for $\mathrm{pH}$ and temperature. Carbon 2015, 82, 87-95. [CrossRef] 
28. Chen, B.; Li, F.; Li, S.; Weng, W.; Guo, H.; Guo, T.; Zhang, X.; Chen, Y.; Huang, T.; Hong, X.; et al. Large scale synthesis of photoluminescent carbon nanodots and their application for bioimaging. Nanoscale 2013, 5, 1967-1971. [CrossRef] [PubMed]

29. Qu, D.; Zheng, M.; Du, P.; Zhou, Y.; Zhang, L.; Li, D.; Tan, H.; Zhao, Z.; Xie, Z.; Sun, Z. Highly luminescent S, N co-doped graphene quantum dots with broad visible absorption bands for visible light photocatalysts. Nanoscale 2013, 5, 12272-12277. [CrossRef]

30. Zhu, H.; Wang, X.; Li, Y.; Wang, Z.; Yang, F.; Yang, X. Microwave synthesis of fluorescent carbon nanoparticles with electrochemiluminescence properties. Chem. Commun. 2009, 34, 5118-5120. [CrossRef]

31. Zhou, J.; Booker, C.; Li, R.; Zhou, X.; Sham, T.-K.; Sun, X.; Ding, Z. An Electrochemical Avenue to Blue Luminescent Nanocrystals from Multiwalled Carbon Nanotubes (MWCNTs). J. Am. Chem. Soc. 2007, 129, 744-745. [CrossRef]

32. Wang, L.; Wang, X.; Bhirde, A.; Cao, J.; Zeng, Y.; Huang, X.; Sun, Y.; Liu, G.; Chen, X. Carbon-Dot-Based Two-Photon Visible Nanocarriers for Safe and Highly Efficient Delivery of siRNA and DNA. Adv. Health Mater. 2014, 3, 1203-1209. [CrossRef]

33. Park, S.Y.; Lee, H.U.; Park, E.S.; Lee, S.C.; Lee, J.-W.; Jeong, S.W.; Kim, C.H.; Lee, Y.-C.; Huh, Y.S.; Lee, J. Photoluminescent Green Carbon Nanodots from Food-Waste-Derived Sources: Large-Scale Synthesis, Properties, and Biomedical Applications. ACS Appl. Mater. Interfaces 2014, 6, 3365-3370. [CrossRef] [PubMed]

34. Tabish, T.A.; Zhang, S. Graphene quantum dots: Synthesis, properties, and biological applications. Compr. Nanosci. Nanotechnol. 2016, 3, 171-192.

35. Xia, C.; Zhu, S.; Feng, T.; Yang, M.; Yang, B. Evolution and Synthesis of Carbon Dots: From Carbon Dots to Carbonized Polymer Dots. Adv. Sci. (Weinh) 2019, 6, 1901316. [CrossRef]

36. Chung, Y.J.; Kim, J.; Park, C.B. Photonic Carbon Dots as an Emerging Nanoagent for Biomedical and Healthcare Applications. ACS Nano 2020, 14, 6470-6497. [CrossRef] [PubMed]

37. Adrita, S.H.; Tasnim, K.N.; Ryu, J.H.; Sharker, S.M. Nanotheranostic Carbon Dots as an Emerging Platform for Cancer Therapy. J. Nanotheranostics 2020, 1, 58-77. [CrossRef]

38. Liu, J.; Li, R.; Yang, B. Carbon Dots: A New Type of Carbon-Based Nanomaterial with Wide Applications. ACS Central Sci. 2020, 6, 2179-2195. [CrossRef]

39. Sahiner, N.; Suner, S.S.; Sahiner, M.; Silan, C. Nitogen and sulphur doped carbon dots from amino acids for potential bio-medical applications. J. Fluoresc. 2019, 29, 1191-1200. [CrossRef]

40. Dong, Y.; Pang, H.; Bin Yang, H.; Guo, C.; Shao, J.; Chi, Y.; Li, C.M.; Yu, T. Carbon-Based Dots Co-doped with Nitrogen and Sulfur for High Quantum Yield and Excitation-Independent Emission. Angew. Chem. Int. Ed. Engl. 2013, 52, 7800-7804. [CrossRef]

41. Xu, J.; Zhou, Y.; Cheng, G.; Dong, M.; Liu, S.; Huang, C. Carbon dots as a luminescence sensor for ultrasensitive detection of phosphate and their bioimaging properties. Luminescence 2014, 30, 411-415. [CrossRef] [PubMed]

42. Zhuo, Y.; Miao, H.; Zhong, D.; Zhu, S.; Yang, X. One-step synthesis of high quantum-yield and excitation-independent emission carbon dots for cell imaging. Mater. Lett. 2015, 139, 197-200. [CrossRef]

43. Hu, L.; Sun, Y.; Li, S.; Wang, X.; Hu, K.; Wang, L.; Liang, X.-J.; Wu, Y. Multifunctional carbon dots with high quantum yield for imaging and gene delivery. Carbon 2014, 67, 508-513. [CrossRef]

44. Fiorito, S.; Serafino, A.; Andreola, F.; Togna, A.; Togna, G. Toxicity and Biocompatibility of Carbon Nanoparticles. J. Nanosci. Nanotechnol. 2006, 6, 591-599. [CrossRef]

45. Li, Q.; Ohulchanskyy, T.Y.; Liu, R.; Koynov, K.; Wu, D.; Best, A.; Kumar, R.; Bonoiu, A.; Prasad, P.N. Photoluminescent Carbon Dots as Biocompatible Nanoprobes for Targeting Cancer Cells in Vitro. J. Phys. Chem. C 2010, 114, 12062-12068. [CrossRef]

46. Zhang, Y.; Pan, H.; Zhang, P.; Gao, N.; Lin, Y.; Luo, Z.; Li, P.; Wang, C.; Liu, L.; Pang, D.; et al. Functionalized quantum dots induce proinflammatory responses in vitro: The role of terminal functional group-associated endocytic pathways. Nanoscale 2013, 5, 5919-5929. [CrossRef]

47. Huczko, A.; Lange, H.; Calko, E. Short Communication: Fullerenes: Experimental Evidence for a Null Risk of Skin Irritation and Allergy. Full Sci. Technol. 1999, 7, 935-939. [CrossRef]

48. Aoshima, H.; Saitoh, Y.; Ito, S.; Yamana, S.; Miwa, N. Safety evaluation of highly purified fullerenes (HPFs): Based on screening of eye and skin damage. J. Toxicol. Sci. 2009, 34, 555-562. [CrossRef]

49. Baker, S.N.; Baker, G.A. Luminescent Carbon Nanodots: Emergent Nanolights. Angew. Chem. Int. Ed. 2010, 49, 6726-6744. [CrossRef]

50. Zhang, J.; Yu, S.-H. Carbon dots: Large-scale synthesis, sensing and bioimaging. Mater. Today 2016, 19, 382-393. [CrossRef]

51. Li, S.; Guo, Z.; Feng, R.; Zhang, Y.; Xue, W.; Liu, Z. Hyperbranched polyglycerol conjugated fluorescent carbon dots with improved in vitro toxicity and red blood cell compatibility for bioimaging. RSC Adv. 2017, 7, 4975-4982. [CrossRef]

52. Khiev, D.; Mohamed, Z.A.; Vichare, R.; Paulson, R.; Bhatia, S.; Mohapatra, S.; Volo, G.P.; Valapala, M.; Kerur, N.; Passaglia, C.L.; et al. Emerging nano-formulations and nanomedicines applications for ocuar drug delivery. Nanomaterials 2021, 11, 173. [CrossRef] [PubMed]

53. Tabish, T.A.; Scotton, C.J.; Ferguson, D.C.J.; Lin, L.; Van Der Veen, A.; Lowry, S.; Ali, M.; Jabeen, F.; Winyard, P.G.; Zhang, S. Biocompatibility and toxicity of graphene quantum dots for potential application in photodynamic therapy. Nanomedicine 2018, 13, 1923-1937. [CrossRef]

54. Tabish, T.A.; Zhang, S.; Winyard, P.G. Developing the next generation of graphene-based platforms for cancer therapeutics: The potential role of reactive oxygen species. Redox Biol. 2018, 15, 34-40. [CrossRef] [PubMed] 
55. Sharma, A.; Das, J. Small molecules derived carbon dots: Synthesis and applications in sensing, catalysis, imaging, and biomedicine. J. Nanobiotechnol. 2019, 17, 1-24. [CrossRef]

56. Esfandiari, N.; Bagheri, Z.; Ehtesabi, H.; Fatahi, Z.; Tavana, H.; Latifi, H. Effect of carbonization degree of carbon dots on cytotoxicity and photo-induced toxicity to cells. Heliyon 2019, 5, e02940. [CrossRef] [PubMed]

57. Algarra, M.; Martin, M.P.; Cifuentes-Rueda, M.; Jiménez-Jiménez, J.; Da Silva, J.C.G.E.; Bandosz, T.J.; Rodríguez-Castellón, E.; Navarrete, J.T.L.; Casado, J. Carbon dots obtained using hydrothermal treatment of formaldehyde. Cell imaging in vitro. Nanoscale 2014, 6, 9071-9077. [CrossRef]

58. Wei, Y.; Jin, X.; Kong, T.; Zhang, W.; Zhu, B. The endocytic pathways of carbon dots in human adenoid cystic carcinoma cells. Cell Prolif. 2019, 52, e12586. [CrossRef] [PubMed]

59. Oh, N.; Park, J.H. Endocytosis and exocytosis of nanoparticles in mammalian cellss. Int. J. Nanomed. 2014, 9, 51-63.

60. Mooren, O.L.; Galletta, B.J.; Cooper, J.A. Roles for Actin Assembly in Endocytosis. Annu. Rev. Biochem. 2012, 81, 661-686. [CrossRef]

61. Roth, T.F.; Porter, K.R. YOLK PROTEIN UPTAKE IN THE OOCYTE OF THE MOSQUITO AEDES AEGYPTI. L. J. Cell Biol. 1964, 20, 313-332. [CrossRef]

62. Palade, G.E. Fine structure of blood capillaries. J. Appl. Phys. 1953, 24, 1424.

63. Cavalli, V.; Vilbois, F.; Corti, M.; Marcote, M.J.; Tamura, K.; Karin, M.; Arkinstall, S.; Gruenberg, J. The stress-induced MAP kinase p38 regulates endocytotic trafficking via the GDI:Rab5 complex. Mol. Cell 2001, 7, 421-432. [CrossRef]

64. Wang, H.-J.; Zhang, J.; Liu, Y.-H.; Luo, T.-Y.; He, X.; Yu, X.-Q. Hyaluronic acid-based carbon dots for efficient gene delivery and cell imaging. RSC Adv. 2017, 7, 15613-15624. [CrossRef]

65. He, X.; Chen, P.; Zhang, J.; Luo, T.-Y.; Wang, H.-J.; Liu, Y.-H.; Yu, X.-Q. Cationic polymer-derived carbon dots for enhanced gene delivery and cell imaging. Biomater. Sci. 2019, 7, 1940-1948. [CrossRef]

66. Cheng, L.; Li, Y.; Zhai, X.; Xu, B.; Cao, Z.; Liu, W. Polycation-b-Polyzwitterion Copolymer Grafted Luminescent Carbon Dots As a Multifunctional Platform for Serum-Resistant Gene Delivery and Bioimaging. ACS Appl. Mater. Interfaces 2014, 6, $20487-20497$. [CrossRef]

67. Pierrat, P.; Wang, R.; Kereselidze, D.; Lux, M.; Didier, P.; Kichler, A.; Pons, F.; Lebeau, L. Efficient in vitro and in vivo pulmonary delivery of nucleic acid by carbon dot-based nanocarriers. Biomaterials 2015, 51, 290-302. [CrossRef]

68. Wu, Y.-F.; Wu, H.-C.; Kuan, C.-H.; Lin, C.-J.; Wang, L.-W.; Chang, C.-W.; Wang, T.-W. Multi-functionalized carbon dots as theranostic nanoagent for gene delivery in lung cancer therapy. Sci. Rep. 2016, 6, 21170. [CrossRef] [PubMed]

69. Yang, X.; Wang, Y.; Shen, X.; Su, C.; Yang, J.; Piao, M.; Lin, Q. One-step synthesis of photoluminescent carbon dots with excita-tion-independent emission for selective bioimaging and gene delivery. J. Colloid Interface Sci. 2017, 492, 1-7. [CrossRef] [PubMed]

70. Zhang, M.; Zhao, X.; Fang, Z.; Niu, Y.; Lou, J.; Wu, Y.; Du, F. Fabrication of HA/PEI-functionalized carbon dots for tumor tar-geting, intracellular imaging and gene delivery. RSC Adv. 2017, 7, 3369-3375. [CrossRef]

71. Chen, J.; Wang, Q.; Zhou, J.; Deng, W.; Yu, Q.; Cao, X.; Wang, J.; Shao, F.; Li, Y.; Ma, P.; et al. Porphyra polysaccharide-derived carbon dots for non-viral co-delivery of different gene combinations and neuronal differentiation of ectodermal mesenchymal stem cells. Nanoscale 2017, 9, 10820-10831. [CrossRef] [PubMed]

72. Zuo, G.; Xie, A.; Pan, X.; Su, T.; Li, J.; Dong, W. Fluorine-Doped Cationic Carbon Dots for Efficient Gene Delivery. ACS Appl. Nano Mater. 2018, 1, 2376-2385. [CrossRef]

73. Jian, H.-J.; Wu, R.-S.; Lin, T.-Y.; Li, Y.-J.; Lin, H.-J.; Harroun, S.G.; Lai, J.-Y.; Huang, C.-C. Super-Cationic Carbon Quantum Dots Synthesized from Spermidine as an Eye Drop Formulation for Topical Treatment of Bacterial Keratitis. ACS Nano 2017, 7, 6703-6716. [CrossRef]

74. Hahn, S.K.; Beack, S.; Choi, J.S.; Joo, C.K. Treatment of Retinitis Pigmentosa Using Hyaluronic Acid-Carbon Nanomateri-AlPhotosensitizer Complex. U.S. Patent 20170274005A1, 28 September 2017.

75. Hasanzadeh, A.; Radmanesh, F.; Kiani, J.; Bayandori, M.; Fatahi, Y.; Aref, A.R.; Karimi, M. Photoluminescent functionalized carbon dots for CRISPR delivery: Synthesis, optimization and cellular investigation. Nanotechnology 2019, 30, 135101. [CrossRef] [PubMed]

76. Yang, T.-C.; Chang, C.-Y.; Yarmishyn, A.A.; Mao, Y.-S.; Yang, Y.-P.; Wang, M.-L.; Hsu, C.-C.; Yang, H.-Y.; Hwang, D.-K.; Chen, S.-J.; et al. Carboxylated nanodiamond-mediated CRISPR-Cas9 delivery of human retinoschisis mutation into human iPSCs and mouse retina. Acta Biomater. 2020, 101, 484-494. [CrossRef]

77. Shoval, A.; Markus, A.; Zhou, Z.; Liu, X.; Cazelles, R.; Willner, I.; Mandel, Y. Anti-VEGF-Aptamer modofied C-dots-A hybrid nanocomposite for troical treatment of ocular vascular disorders. Nano Micro Small 2019, 15, 1902776.

78. Zhu, S.; Song, Y.; Zhao, X.; Shao, J.; Zhang, J.; Yang, B. The photoluminescence mechanism in carbon dots (graphene quantum dots, carbon nanodots, and polymer dots): Current state and future perspective. Nano Res. 2015, 8, 355-381. [CrossRef] 